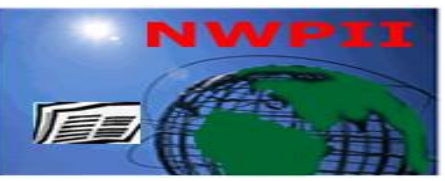

American Journal of Biomedical Sciences

ISSN: 1937-9080

nwpii.com/ajbms

\title{
Evaluation of Antioxidant Parameters in Contraceptive Users in Family Planning Centres in Kaduna State, Nigeria
}

\section{Ebirien-Agana Samuel Bartimaeus ${ }^{1 *}$, Maria Ogochukwu Egbuna ${ }^{1}$, Zachaeus Awortu Jeremiah ${ }^{2}$ and Stella Urekweru Ken-Ezihuo ${ }^{1}$}

\author{
${ }^{1}$ Department of Medical Laboratory Science, Rivers State University, P.M.B. 5080, Nkpolu-Oroworukwo, \\ Port Harcourt, Rivers State, Nigeria. \\ ${ }^{2}$ Department of Medical Laboratory Science, Faculty of Basic Medical Sciences, College of Health Sciences, Niger \\ Delta University, Bayelsa State, Nigeria \\ "Corresponding Author \\ Dr Ebirien-Agana Samuel Bartimaeus \\ Department of Medical Laboratory Science, Rivers State University, P.M.B. 5080 \\ Nkpolu-Oroworukwo, Port Harcourt, Rivers State, \\ Nigeria \\ Tel.: +2348033410302 \\ Email: ebbyagana@gmail.com, bartimaeus.ebi@ust.edu.ng
}

Received:02 May 2019; | Revised:27 May 2019; | Accepted:07 December 2019

\begin{abstract}
Purpose: This study was designed to evaluate the levels of oxidative stress parameters in women using progestogen-only contraceptives and compare the levels with population of women not involved with contraceptive use.

Methods: In this cross-sectional study, a total of 250 apparently healthy, non-pregnant, non- smoking women, aged between 18 and 50 years were recruited. 150 women served as the study subjects while 100 healthy non-pregnant women of the age bracket who have never used any contraceptive device constitute the control population. The subjects willingly consented to participate in the study. 5mls of whole blood was collected by standard venipuncture technique from each participant into dipotassium ethylene diamine tetraacetic acid (EDTA) bottle and plasma separated for the determination of catalase, superoxide dismutase, glutathione peroxidase, malondialdehyde and total antioxidant activity using standardized procedures. Values obtained were analyzed statistcally and significance was established at $\mathrm{p}<0.05$.

Results: Result showed that significantly $(\mathrm{p}<0.05)$ elevated mean of $42.24 \pm 6.23 \mu / \mathrm{mg}$ protein and $45.02 \pm 6.07 \mu / \mathrm{mg}$ protein for catalase activity and $24.27 \pm 11.25 \mu \mathrm{mol} / \mathrm{ml} / \mathrm{mg}$ protein and $29.58 \pm 9.87$ for malondialdehyde level for non-contraceptive and contraceptive users were observed. No significant $(p>0.05)$ variation in the means of other natural antioxidants was observed. Also no significant variation in the means of the antioxidants was found between the implant and injectable contraceptive users. Similarly, variation in age class and duration of use of contraceptives did not significantly $(p>0.05)$ affect the activities of the antioxidants in the contraceptive users. However, the correlations of the antioxidant indices levels obtained from the hormonal contraceptives with the age of the subjects and the duration of use of the contraceptives
\end{abstract}


showed that a moderate positive corelation $(\mathrm{r}=0.344)$ and $(\mathrm{r}=0.3258)$ of SOD and GPx was found with the duration of use of the implant contraceptives (combined) while a negative correlation $(\mathrm{r}=-0.388)$ was observed between CAT and duration of use the implant contraceptives respectively.

Conclusion: These results though conflicting brings to the fore the observation that prolonged use of hormonal contraceptives may reverse the lipid peroxidation and tisssue damage initially experienced with hormonal contraceptive use.

Keywords: Contraceptives, Malondialdehyde, Catalase, Superoxide dismutase, Gluthathione peroxidase

\section{Introduction}

Unexpected or unplanned pregnancy poses a major public health challenge in women of childbearing age, especially in developing countries. It has been estimated that out of the 210 million pregnancies that occur every year all over the world, approximately 80 million are unplanned, while about 46 million end in abortion, which account for $20 \%-40 \%$ of maternal deaths in Nigeria. ${ }^{[1]}$ In Nigeria, unintended intercourse is the primary cause of unwanted pregnancies, and many women with unwanted pregnancies decide to end them by abortion. ${ }^{[2]}$ The consequences of these clandestine abortions are grave and can be life-threatening, often leading to maternal death. ${ }^{[3]}$

Since the discovery that oral progestational 19nor steroids could inhibit ovulation, ${ }^{[4]}$ several million women have used different types of synthetic estrogens and progestins to prevent conception.Contraception which is also known as birth control is a device or method used to prevent unintended pregnancy. ${ }^{[5]}$ Hormonal contraceptives are used by millions of women worldwide. Although other methods of contraception exist, the use of oral and injectable contraceptives is the most popular. In the United States, $18 \%$ of women who adopted contraceptive methods to prevent conception relied upon hormonal contraceptives. ${ }^{[6]}$ The NHDS reported the prevalence rate of hormonal contraceptives use among Nigerian women between the ages $15-49$ as $13 \%$ in 2003 , $15 \%$ in 2008 and $18 \%$ in 2012 . Further analysis of the total contraceptive rate in Nigeria also showed wide state variations, ranging from $0.3 \%$ in Jigawa to $41.6 \%$ in Lagos state as well as zonal variations ranging from $2.7 \%$ in the northwest to $28.5 \%$ in the southwest. ${ }^{[7]}$
Several lines of evidence have proved that exogenous hormones, including COCs induce oxidative stress resulting in the depletion of serum antioxidants. ${ }^{[8-10]}$ OS is caused by an imbalance between antioxidants and reactive ROS production. ${ }^{[11]}$ ROS are byproducts of normal cellular metabolism. Low and moderate amounts of ROS have beneficial effects on several physiological processes while overproduction of it can cause oxidative damage to biomolecules, eventually leading to many chronic diseases such as atherosclerosis, cancer, osteoarthritis etc. ${ }^{[10]}$

Antioxidants on the other hand are substances that delays, prevents or removes oxidative damage to target molecule which may be enzymatic SOD, CAT, GPx and GSH or non- enzymatic (vitamins and minerals such as vitamin $\mathrm{C}$, vitamin $\mathrm{E}$, selenium and zinc). ${ }^{[12]}$ Osman et al reported highly significant decreases in SOD, CAT activities and GSH level in pancreatic tissues of COC treated rats accompanied by a highly significant increase in MDA level as compared to control group. ${ }^{[13]}$

Oxidative stress is associated with the development of several disorders including cardiovascular disease and cancer. Among conditions known to influence oxidative stress, the use of contraception in women has been a matter of ongoing discussion. Ever since the introduction of these drugs in Nigeria, data are scarce about their relationship with oxidative stress and the topic still remains a subject of debate.

This study was, therefore, designed to evaluate the levels of oxidative stress parameters in women using progestogen-only contraceptives and compare the levels with population of women not involved with contraceptive use. 


\section{Materials and Methods}

\subsection{Description of study area}

This comparative cross sectional study among women using progestogen-only injectable contraceptives and contraceptive implants was carried out in Yusuf Dantsoho Memorial Hospital Kaduna and Primary Health Centre Kaduna. Kaduna State is located between latitude $900 \mathrm{~N}$ and $1200 \mathrm{~N}$ of the equator and longitude $600 \mathrm{E}$ and $900 \mathrm{E}$ of the prime meridian. The climate varies from the Northern to the Southern part of the state with an annual mean temperature of between $24^{\circ} \mathrm{C}$ and $29^{\circ} \mathrm{C}$, the length of rainfall varies between 150 days to 190 days, an annual rainfall of between $150 \mathrm{~mm}$ to $200 \mathrm{~mm}$, and relative humidity ranging between $20 \%$ and $30 \%$ in January, rising to between $60 \%$ and $80 \%$ in July. Vegetation divides into northern Guinea savannah in the north and southern Guinea savannah in the south of the state.

\subsection{Study population}

The total study population consists of two hundred and fifty (250) apparently healthy, nonpregnant, non- smoking women, aged between 18 and 50 years, without underlying disease condition that could affect their physiological system, who attended the family planning Clinic of Yusuf Dantsoho Memorial Hospital and Primary Healthcare Centre in Kaduna State. One hundred and fifty (150) women out of the total population serve as the study subjects while one hundred (100) healthy non-pregnant women of the same age bracket who have never used any family planning method and or hormonal contraceptive constituted the control participants.

\subsection{Injectables and implants contraceptives}

The progestogen-only injectable contraceptives considered in the study were Depomedroxyprogesterone acetate (DMPA), which is usually delivered intramuscularly (i.m) at a dose of $150 \mathrm{mg} / 1.0 \mathrm{~mL}$ in every 12 weeks; Sayana press, a lower dose formulation of DMPA, often given subcutaneously (s.c) at a dose of $104 \mathrm{mg} / 0.65 \mathrm{~mL}$ and Noristerat-Norethisteron Enanthate (NET-EN), delivered by intramuscular injection at a dose of $200 \mathrm{mg} / \mathrm{mL}$ every 8 weeks ${ }^{[14]}$. The implant contraceptives included the two-rod Jadelle ${ }^{\circledR}$, a subcutaneous hormonal contraceptive containing $150 \mathrm{mg}$ of levonorgestrel (LNG), $75 \mathrm{mg}$ in each rod and supplied as a single trocar offering contraceptive protective for five years and implanon, a single-rod contraceptive implant measuring $40 \mathrm{~mm}$ x $2 \mathrm{~mm}$, and contains $68 \mathrm{mg}$ of etonogestrel (ENG) dispersed in a membrane of ethylene vinyl acetate ${ }^{[15]}$ and licensed for three years use. ${ }^{[16]}$

\subsection{Ethical approval}

The study was approved by the Research Ethical Committee of the Kaduna State Ministry of Health and Primary Healthcare Centre, Kaduna. In addition each of the participants in this study gave informed consent to participate.

\subsection{Inclusion Criteria}

The entire contraceptive users were subjects who are aged between 18 and 50 years, sexually active, normotensive females using long acting contraceptives for a period of at least 2months and above. Only women who willing voluntered to participate in the study, non-pregnant and not smoking and were on implant and progestogen only injectable contraceptives without underlying disease condition were recruited.

\subsection{Exclusion Criteria}

Exclusion criteria included; age $(<18$ years or $>50$ years), COC use or combined injectable contraceptives, non - hormonal contraceptive use and contraceptive use of $<2$ months, hypertensive, presence of underlying disease condition that could affect their clotting system and failure to give informed consent to participate in the study.

The blood pressure and weight of the subjects were determined by the nurses working in the family planning Clinic. Informations on age, duration of contraceptive use, menstrual flow status, parity, history of disease and reaction to the contraceptives were obtained from the patients using a structured questionnaire.

\subsection{Sample size calculation}

The sample size was calculated using the formular by Naing et al. ${ }^{[17]}$ Prevalence of modern contraceptive use in Nigeria is $9.9 \%{ }^{[18]}$. 


\subsection{Blood sample collection and storage}

Five milliliters $(5 \mathrm{mls})$ of whole blood was collected by standard venipuncture technique as described by Lewis et al. from each participant into dipotassium ethylene diamine tetra-acetic acid (EDTA) bottle after which it was spun and the plasma component separated into a plain tube for antioxidant variables (catalase, superoxide dismutase, glutathione peroxidase, malondialdehyde and total antioxidant activity) ${ }^{[19]}$. The plasma was stored in stoppered tubes and used within 4 hours of venepuncture.

\subsection{Assay of SOD activity}

The enzyme was assayed by the method described by Fridovich involving the inhibition of auto oxidation of adrenaline by superoxide dismutase at $\mathrm{pH} 10.2$ producing a mixture whose absorbance was read at $480 \mathrm{~nm}^{[20]}$.

\subsection{Estimation of MDA levels}

MDA, a marker of Lipid peroxidation was determined as thiobarbituric acid reactive substance according to Okhawa et al [21] with slight modification by Atawodi et al using trichloroacetic acid (TCA) and thiobarbituric acid. The product of the reaction is a coloured complex which was measured at $533 \mathrm{~nm}^{[22]}$.

\subsection{Estimation of CAT activity}

CAT activity was measured using Aebi's method ${ }^{[23]}$. Exactly 10ul of serum was added to test tube containing $2.80 \mathrm{ml}$ of $50 \mathrm{mM}$ potassium phosphate buffer $(\mathrm{pH} 7.0)$. The reaction was initiated by adding $0.1 \mathrm{ml}$ of freshly prepared $30 \mathrm{mM}$ and the decomposition rate of were measured at $240 \mathrm{~nm}$ for 5 minutes on a spectrophotometer.

\subsection{Estimation of GPx activity}

GPx was measured using the method as described by Rotruck et al. The reaction was made

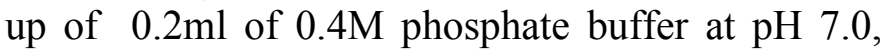
$0.1 \mathrm{ml}$ of $10 \mathrm{mM}$ sodium azide, $0.2 \mathrm{ml}$ reduced gluthathione and $0.1 \mathrm{ml}$ of hydrogen peroxide. The content was then incubated for 10 to 15 minutes at $37^{\circ} \mathrm{C}$. After incubation $0.4 \mathrm{ml}$ of $10 \%$ TCA was added to stop the reaction and centrifuged at $3200 \mathrm{~g}$ for 20 minutes. The supernatant was assayed for gluthathione peroxidase content using Ellmans reagent (19.8 mg 5 -5 - dithiobisnitrobenzoic acid (DTNB) in $100 \mathrm{ml}$ of $0.1 \%$ sodium nitrate) ${ }^{[24]}$.

\subsection{Estimation of TAA activity}

TAA was determined according to the method described by Buico et al. Preformed radical monocation of 2,2-azinobis-(3 ethyl benzothiazoline 6 sulfonic acid) (ABTS), a blue green chromophore was generated by reacting $7 \mathrm{M}$ ABTS stock solution with $2.45 \mathrm{M}$ potassium persulfate solution in acetate buffer (PH 4.5). The solution was kept in the dark at room temperature for 12 to 24 hours before use. The ABTS solution was diluted to an absorbance of 1.00 at $734 \mathrm{~nm}$. $50 \mu \mathrm{l}$ of sample was added to $950 \mu \mathrm{l}$ of diluted ABTS. The sample was properly mixed and incubated in the dark in a water bath at $370 \mathrm{C}$ for 20 minutes. The absorbance was read at $734 \mathrm{~nm}$. Trolox was used for the calibration of the method. Inhibition of absorbance level versus trolox concentration curve was used to express the serum/plasma TAC in trolox equivalent ${ }^{[25]}$.

\subsection{Statistical analysis}

All descriptive statistical analysis was done using SAS 9.0 Software, manufactured by SAS Institute Inc. USA. Comparison between two factors was analyzed using Student t-test while comparisons among three or more factors were analyzed using one-way analysis of variance (ANOVA). The Tukey test of multiple comparison was used for comparison of means that showed significant difference. Phenotypic correlations between variables were computed using Spearman correlation. Significance was established at $p<0.05$.

\section{Results}

The comparison of the means $\pm \mathrm{SD}$ of the antioxidant indices between the contraceptive and non-contraceptive users is shown in table 1 . The table shows that the mean $\pm \mathrm{SD}$ of the activities of SOD, CAT and GPx in the contraceptive users were $25.03 \pm 7.79 \mu / \mathrm{ml}, 45.02 \pm 6.07 \mu / \mathrm{mg}$ protein and $27.53 \pm 12.12 \mu \mathrm{g} / \mathrm{ml}$ respectively while the activities of these enzymes in the non-contraceptive users were $25.90 \pm 6.23 \mu / \mathrm{ml}, 42.24 \pm 6.23 \mu / \mathrm{mg}$ protein and $30.43 \pm 10.86 \mu \mathrm{g} / \mathrm{ml}$ respectively. While the activity of catalase was significantly 
$(\mathrm{p}<0.05)$ increased between the two groups, the activities of SOD and GPx between the two groups did not show any significant $(p>0.05)$ change. The levels of MDA and TAA in the contraceptive users were $29.58 \pm 9.87 \mu \mathrm{mol} / \mathrm{ml} / \mathrm{mg}$ protein and $24.09 \pm$ $5.31 \mathrm{Umol} /$ trolox eq while in the non-contraceptive users the levels were and $24.27 \pm 11.25$ $\mu \mathrm{mol} / \mathrm{ml} / \mathrm{mg}$ protein and $24.08 \pm 4.63 \mathrm{Umol} /$ trolox eq respectively. However, while the level of MDA was significantly $(p<0.05)$ increased in the contraceptive users, no significant ( $p>0.05$ ) increase was seen in the level of the total antioxidant activity between the two groups.

Table 1: Comparison of Mean \pm SD of antioxidant indices of women on contraceptives and control subjects

\begin{tabular}{|c|c|c|c|}
\hline \multirow{2}{*}{ Parameters } & \multicolumn{2}{|c|}{ Groups } & \multirow{2}{*}{ P-value } \\
\cline { 2 - 3 } & Non-contraceptive users & Contraceptive users & 0.5055 \\
\hline SOD $(\mu / \mathrm{ml})$ & $25.90 \pm 6.23^{\mathrm{a}}$ & $25.03 \pm 7.79^{\mathrm{a}}$ & $0.0104^{*}$ \\
\hline CAT (U/mg protein) & $42.24 \pm 6.23^{\mathrm{a}}$ & $45.02 \pm 6.07^{\mathrm{b}}$ & $0.0034^{*}$ \\
\hline MDA(Umol/mg protein) & $24.27 \pm 11.25^{\mathrm{a}}$ & $29.58 \pm 9.87^{\mathrm{b}}$ & 0.1639 \\
\hline GPx $(\mu \mathrm{g} / \mathrm{ml})$ & $30.43 \pm 10.86^{\mathrm{a}}$ & $27.53 \pm 12.12^{\mathrm{a}}$ & 0.9936 \\
\hline TAA (Umol/trolox eq) & $24.08 \pm 4.63^{\mathrm{a}}$ & $24.09 \pm 5.31^{\mathrm{a}}$ & \\
\hline
\end{tabular}

Notes: Means \pm SD with different superscripts ( $\mathrm{a}$ and $\mathrm{b}$ ) differ significantly, ${ }^{*} \mathrm{P}<0.05$; SD-Standard deviation, $\mathrm{SOD}=$ Superoxide Dismutase; $\mathrm{CAT}=$ Catalase; $\mathrm{MDA}=$ Malondialdehyde; $\mathrm{GPx}=$ Glutathione Peroxidase; $\mathrm{TAA}=\mathrm{Total}$ Antioxidant Activity.

Similarly, the comparison of the mean \pm SD of antioxidant indices of women on implants and injectable contraceptives is shown in table 2. The activities of SOD, CAT, and GPx were 23.61 \pm 7.08 $\mu / \mathrm{ml}, 44.85 \pm 6.35 \mathrm{U} / \mathrm{mg}$ protein and $27.69 \pm 9.99$ $\mu \mathrm{g} / \mathrm{ml}$ and $25.62 \pm 8.03 \mu / \mathrm{ml}, \quad 45.18 \pm 5.94 \mu / \mathrm{mg}$ protein and $27.47 \pm 12.94 \mu \mathrm{g} / \mathrm{ml}$ respectively. No significant difference increase in the activities of these antioxidant enzymes between the implant and injectable contraceptives. The levels of MDA and TAA for the implants and injectables were $29.18 \pm 9.15 \mathrm{Umol} / \mathrm{mg}$ protein and $25.40 \pm 5.65$ Umol/trolox eq and $29.75 \pm 10.19 \mathrm{Umol} / \mathrm{mg}$ protein and $23.45 \pm 5.08$ Umol/trolox eq respectively. A significant decrease $(p<0.05)$ was observed in the level of total antioxidant activity between injectables and implant contraceptives.

Table 2: Comparison of Mean \pm SD of antioxidant indices of women on implants and injectable contraceptives

\begin{tabular}{|c|c|c|c|}
\hline \multirow{2}{*}{ Parameters } & \multicolumn{2}{|c|}{ Groups } & \multirow{2}{*}{ P-value } \\
\cline { 2 - 4 } & Implant $(\mathbf{n = 6 3})$ & Injectables (n=87) & 0.1765 \\
\hline SOD $(\mu / \mathrm{ml})$ & $23.61 \pm 7.08^{\mathrm{a}}$ & $25.62 \pm 8.03^{\mathrm{a}}$ & 0.7698 \\
\hline CAT $(\mathrm{U} / \mathrm{mg}$ protein) & $44.85 \pm 6.35^{\mathrm{a}}$ & $45.18 \pm 5.94^{\mathrm{a}}$ & 0.7616 \\
\hline MDA(Umol/mg protein) & $29.18 \pm 9.15^{\mathrm{a}}$ & $29.75 \pm 10.19^{\mathrm{a}}$ & 0.9236 \\
\hline GPx $(\mu \mathrm{g} / \mathrm{ml})$ & $27.69 \pm 9.99^{\mathrm{a}}$ & $27.47 \pm 12.94^{\mathrm{a}}$ & $0.0526^{*}$ \\
\hline TAA (Umol/trolox eq) & $25.40 \pm 5.65^{\mathrm{a}}$ & $23.45 \pm 5.08^{\mathrm{b}}$ & \\
\hline
\end{tabular}

Notes: Means with different superscripts ( $\mathrm{a}$ and $\mathrm{b}$ ) differ significantly, $* \mathrm{P}<0.05$. $\mathrm{SOD}=$ Superoxide Dismutase;

$\mathrm{CAT}=$ Catalase; $\mathrm{MDA}=$ Malondialdehyde; $\mathrm{GPx}=$ Glutathione Peroxidase; TAA=Total Antioxidant Activity. 
The effect of the routes of administration of the contraceptives was also investigated and the findings shown in the table 3 . The mean $\pm \mathrm{SD}$ of SOD, CAT and GPx obtained from subjects who were administer the contraceptive intramuscularly were $25.30 \pm 8.10 \mu / \mathrm{ml}, 45.57 \pm 5.80 \mathrm{U} / \mathrm{mg}$ protein and $26.56 \pm 12.68 \mu \mathrm{g} / \mathrm{ml}$ while the value for the subcutaneous route of administration were $24.51 \pm$ $7.21 \mu / \mathrm{ml}, 44.13 \pm 6.46 \mu / \mathrm{mg}$ protein and $29.45 \pm$ $10.79 \mu \mathrm{g} / \mathrm{ml}$ respectively. The comparison of the means of the activities of these antioxidant enzymes based on the routes of administration did not show ant significant difference $(p>0.05)$. The level of MDA and TAA in the subjects who recieved the device by intramuscular route of administration were $26.56 \pm 12.68 \mathrm{Umol} / \mathrm{mg}$ protein and $23.09 \pm$ 4.75 Umol/trolox eq while in those who were administered by subcutaneous route, the levels were $28.13 \pm 9.22 \mathrm{Umol} / \mathrm{mg}$ protein and $25.85 \pm 5.90$ Umol/trolox eq respectively. The total antioxidant activity was significantly different $(p<0.05)$ between the two routes.

Table 3: Comparison of Mean \pm SD values of antioxidant indices based on route of contraceptive administration

\begin{tabular}{|c|c|c|c|}
\hline \multirow{2}{*}{ Parameters } & \multicolumn{2}{|c|}{ Route of administration } & \multirow{2}{*}{ P-value } \\
\cline { 2 - 4 } & Intramuscular (n=72) & Subcutaneous (n=78) & \\
\hline SOD $(\mu / \mathrm{ml})$ & $25.30 \pm 8.10^{\mathrm{a}}$ & $24.51 \pm 7.21^{\mathrm{a}}$ & 0.5703 \\
\hline CAT $(\mathrm{U} / \mathrm{mg}$ protein) & $45.57 \pm 5.80^{\mathrm{a}}$ & $44.13 \pm 6.46^{\mathrm{a}}$ & 0.1944 \\
\hline MDA(Umol/mg protein) & $30.32 \pm 10.15^{\mathrm{a}}$ & $28.13 \pm 9.22^{\mathrm{a}}$ & 0.2259 \\
\hline GPx $(\mu \mathrm{g} / \mathrm{ml})$ & $26.56 \pm 12.68^{\mathrm{a}}$ & $29.45 \pm 10.79^{\mathrm{a}}$ & 0.1935 \\
\hline TAA (Umol/trolox eq) & $23.09 \pm 4.75^{\mathrm{a}}$ & $25.85 \pm 5.90^{\mathrm{b}}$ & $0.0041^{*}$ \\
\hline
\end{tabular}

Notes:Means with different superscripts $\left(\mathrm{a}\right.$ and $\mathrm{b}$ ) differ significantly, ${ }^{*} \mathrm{P}<0.05$. $\mathrm{SOD}=$ Superoxide Dismutase; $\mathrm{CAT}=$ Catalase; $\mathrm{MDA}=$ Malondialdehyde; $\mathrm{GPx}=$ Glutathione Peroxidase; TAA=Total Antioxidant Activity.

Furthermore, the contraceptive users were stratified into age classes to investigate the impact of age classification on the antioxidant levels and the result is shown in table 4 . The analysis showed that between the age classes of 18-27years, 2837 years and $\geq 38$ years, there was no significant difference $(\mathrm{p}>0.05)$ in the activities and levels of the antioxidant indices amongst the contraceptive users.

Table 4: Comparison of Mean \pm SD values of antioxidant indices of contraceptive users based on age

\begin{tabular}{|c|c|c|c|c|}
\hline \multirow[b]{2}{*}{ Parameters } & \multicolumn{3}{|c|}{ Age group } & \multirow[b]{2}{*}{ P-value } \\
\hline & 18-27years $(n=51)$ & $28-37$ years $(n=62)$ & $\geq 38(n=37)$ & \\
\hline $\operatorname{SOD}(\mu / \mathrm{ml})$ & $20.14 \pm 0.20^{\mathrm{a}}$ & $23.03 \pm 7.50^{\mathrm{a}}$ & $23.45 \pm 9.29^{\mathrm{a}}$ & 0.6551 \\
\hline CAT (U/mg protein) & $46.29 \pm 11.11^{\mathrm{a}}$ & $46.14 \pm 6.03^{\mathrm{a}}$ & $45.03 \pm 4.63^{\mathrm{a}}$ & 0.5814 \\
\hline MDA(Umol/mg protein) & $34.11 \pm 3.61^{\mathrm{a}}$ & $30.01 \pm 4.20^{\mathrm{a}}$ & $33.05 \pm 12.26^{\mathrm{a}}$ & 0.7316 \\
\hline GPx $(\mu \mathrm{g} / \mathrm{ml})$ & $22.05 \pm 2.41^{\mathrm{a}}$ & $24.43 \pm 10.23^{\mathrm{a}}$ & $24.38 \pm 02.12^{\mathrm{a}}$ & 0.4950 \\
\hline TAA (Umol/trolox eq) & $20.10 \pm 0.45^{\mathrm{a}}$ & $23.15 \pm 5.30^{\mathrm{a}}$ & $21.48 \pm 4.32^{\mathrm{a}}$ & 0.3165 \\
\hline
\end{tabular}

Notes: Means with the same superscript (a) do not differ significantly, P $>0.05$; SD-Standard deviation.

$\mathrm{SOD}=$ Superoxide Dismutase; $\mathrm{CAT}=$ Catalase; $\mathrm{MDA}=$ Malondialdehyde; $\mathrm{GPx}=$ Glutathione Peroxidase; $\mathrm{TAA}=$ Total Antioxidant Activity. 
Attempt was also made to investigate the impact of duration of contraceptive use on the activities and levels of the contraceptives (combined) and the outcome presented in table 5. The duration period of use of the contraceptives (implants and/or injectables) were categorized as $\leq 1$ year, 1-3 years and $\geq 4$ years. The result showed that the length of years that the contraceptives were used did not significantly $(\mathrm{p}>0.05)$ affect the activities and levels of the antioxidant indices studied.

Table 5: Comparison of Mean \pm SD values of antioxidant indices based on duration of contraceptive use

\begin{tabular}{|c|c|c|c|c|}
\hline \multirow{2}{*}{ Parameters } & \multicolumn{3}{|c|}{ Duration of use of contraceptives } & P-value \\
\cline { 2 - 5 } & $\leq \mathbf{1}$ year $(\mathbf{n}=\mathbf{6 3})$ & $\mathbf{1}-\mathbf{3 y e a r s}(\mathbf{n}=\mathbf{4 6})$ & $\mathbf{4}(\mathbf{n}=\mathbf{4 1})$ & \\
\hline SOD $(\mu / \mathrm{ml})$ & $19.15 \pm 0.21^{\mathrm{a}}$ & $25.05 \pm 7.60^{\mathrm{a}}$ & $25.56 \pm 9.31^{\mathrm{a}}$ & 0.5460 \\
\hline CAT $(\mathrm{U} / \mathrm{mg}$ protein) & $49.50 \pm 10.47^{\mathrm{a}}$ & $45.04 \pm 5.87^{\mathrm{a}}$ & $44.86 \pm 6.88^{\mathrm{a}}$ & 0.5809 \\
\hline MDA(Umol/mg protein) & $35.95 \pm 4.17^{\mathrm{a}}$ & $29.39 \pm 9.71^{\mathrm{a}}$ & $30.07 \pm 11.38^{\mathrm{a}}$ & 0.6356 \\
\hline GPx $(\mu \mathrm{g} / \mathrm{ml})$ & $17.05 \pm 3.46^{\mathrm{a}}$ & $27.58 \pm 12.33^{\mathrm{a}}$ & $28.38 \pm 11.12^{\mathrm{a}}$ & 0.4555 \\
\hline TAA $(\mathrm{Umol} /$ trolox eq) & $19.20 \pm 0.42^{\mathrm{a}}$ & $24.20 \pm 5.33^{\mathrm{a}}$ & $23.38 \pm 5.33^{\mathrm{a}}$ & 0.3636 \\
\hline
\end{tabular}

Notes: Means with the same superscript (a) do not differ significantly $\mathrm{P}>0.05$; SD-Standard deviation, $\mathrm{SOD}=$ Superoxide Dismutase; $\mathrm{CAT}=$ Catalase; $\mathrm{MDA}=$ Malondialdehyde; $\mathrm{GPx}=$ Glutathione Peroxidase; $\mathrm{TAA}=\mathrm{Total}$ Antioxidant Activity.

The correlations of the antioxidant indices levels obtained from the hormonal contraceptives with the age of the subjects and the duration of use of the contraceptives is shown in table 6 . A moderate positive corelation $(r=0.344)$ and $(r=$
0.3258) of SOD and GPx was found with the duration of use of the implant contraceptives (combined) while a negative correlation $(r=-0.388)$ was observed between CAT and duration of use the implant contraceptives respectively.

Table 6: Correlation between antioxidant indices with age and duration of contraception among women on injectable and implant contraceptives

\begin{tabular}{|c|c|c|c|c|}
\hline \multirow{2}{*}{ Parameters } & \multicolumn{2}{|c|}{ Injectables } & \multicolumn{2}{c|}{ Implants } \\
\cline { 2 - 5 } & Age (years) & Duration (months) & Age (years) & $\begin{array}{c}\text { Duration } \\
\text { (Months) }\end{array}$ \\
\hline SOD $(\mu \mathrm{g} / \mathrm{ml})$ & 0.0625 & -0.0630 & -0.2637 & $0.344^{*}$ \\
\hline CAT $(\mathrm{U} / \mathrm{mg}$ protein) & 0.0112 & -0.0202 & 0.2694 & $-0.3880^{*}$ \\
\hline MDA $(\mu \mathrm{mol} / \mathrm{mg} /$ protein & 0.1104 & 0.0082 & 0.1932 & 0.1760 \\
\hline GPx $(\mu \mathrm{g} / \mathrm{ml})$ & 0.0944 & 0.0006 & -0.2329 & $0.3258^{*}$ \\
\hline TAA $(\mathrm{Umol} /$ trolex eq) & 0.2631 & -0.003 & 0.0162 & 0.2206 \\
\hline
\end{tabular}

Notes: $\mathrm{SOD}=$ Superoxide dismutase, $\mathrm{CAT}=$ Catalase, $\mathrm{MDA}=$ Malondialdehyde, $\mathrm{GPx}=$ Glutathione Peroxidase, $\mathrm{TAA}$ $=$ Total Antioxidant Activity, ${ }^{*} \mathrm{p}<0.05$ 


\section{Discussion}

The goal of this study was to evaluate the effect of hormonal contraceptives on the oxidative stress status of apparently healthy women administered with contraceptives for family planning purposes in rural communities in Kaduna State, Nigeria. To the best our knowledge, this the first study undertaken on the subject in this part of Nigeria. The result of the present study showed there were significantly $(p<0.05)$ elevated catalase activity and malondialdehyde level in hormonal contraceptive users (combined) when compared with non users. MDA, a marker for oxidative stress, results from lipid peroxidation. Its rise in contraceptive users implies that contraceptive use is capable of causing lipid peroxidation in the tissues of users. This observation is supported by the work of $\mathrm{Zal}$ et al who reported significant increases in plasma malondialdehyde levels, associated with decreased activities of glutathione peroxidase (GPx) and glutathione reductase (GR) in women taking low-dose OCs compared to the control group, thus indicative of increased oxidative stress induced by the hormonal therapy ${ }^{[26]}$.

Dacie et al had reported that the peroxidation of polyunsaturated fatty acids results in the production of malondialdehyde ${ }^{[27]}$. Catalase is a proteinous enzyme that protect cells from oxidative damage caused by reactive oxygen species by catalyzing the decomposition of hydrogen peroxide to water and oxygen ${ }^{[28,29]}$. The increase in the activity of catalase in the face of contraceptive challange does imply that progestogen containing contraceptives have the potential of boosting the production of natural antioxidants such catalase, an opinion that agrees with the findings of Adaramoye et al. and Adedera et al ${ }^{[30,31]}$. Capel et al. and Massafra et al. 33 found that a 9-cycle course of a combined oral contraceptive (ethinylestradiol $20 \mathrm{mg}$ and desogestrel $150 \mathrm{mg}$ ) in young women led to a significant increased activity of antioxidative enzymes, namely catalase and glutathione peroxidase (GPx) ${ }^{[32,33]}$.

Furthermore, significant $(\mathrm{p}<0.05)$ elevation in the total antioxidant activity (TAA) was observed in users administered with hormonal implants when compared with those who used injectable hormonal contraceptives. This finding is in agreement with the study of Adejumo et al. who reported that injectable hormonal contraceptives lower serum toatal antioxidant status of users ${ }^{[10]}$. Palan et al. had earlier reported that hormonal contraceptives deplete antioxidant vitamins and trace elements as measured by the activity of coenzyme Q10, vitamin $\mathrm{E}$ and total antioxidant activity18 although Akinloye et al attributed decrease in the serum levels of antioxidant trace elements more specifically to increased use of oral contraceptives [9]. The older oral contraceptives contained high dose progestogens which was reported to raise triglycerides, low-density lipoprotein cholesterol (LDL-C) and reduce high density lipoprotein cholesterol levels (HDL-C), however, the hormonal contraceptives employed in this study contain lowdose progestogens which according to reports do not appear to affect the lipid profile in users ${ }^{[34]}$. The increased risk of cardiovascular disease in oral contraceptive users may be due to venous or arterial thrombosis ${ }^{[35,36]}$.

The route of drug administration into the patient as well as the pattern of drug distribution markedly affects the extent and time course of drug action. As a result of metabolism of drugs due to its first through the liver, drugs which are rapidly cleared by hepatic processes will show a decreased extent of availability following oral administration [37]. The study revealed that the routes of administration of the hormonal contraceptives into the subjects did not have have major significant impact on the natural antioxidants activities such as SOD, CAT, GPx and MDA level except the total antioxidant activity which was significantly $(p<0.05)$ elevated in subjects that recieved the contraceptives subcutaneously.

The effect of age of subjects on the administered hormonal contraceptives was also investigated and the result revealed that age of the subjects might not have reasonably influenced the activities of antioxidants enzymes (SOD, CAT and GPx), MDA and total antioxidant activity. Advancing age is characterized by impairment in the function of the many regulatory processes that provide functional integration between cells and organs. Therefore,there may be a failure to maintain homeostasis under conditions of physiological stress ${ }^{[38]}$. 
The effect of duration of contraceptive use on the oxidative stress status of subjects did not show any significant variation $(\mathrm{p}>0.05)$ in the activities of SOD, CAT, GPx and TAA level. Similar observation was also noted the level of MDA. However, the activities of SOD and GPx and TAA level insignicantly $(p>0.05)$ increased between those who used the agent for $\leq 1$ year and $\geq 4$ years, the activity of CAT and the level of MDA insignificantly $(p>0.05)$ reduced between the same duration of time. These results though conflicting brings to the fore the observation that prolonged use of hormonal contraceptives may reverse the lipid peroxidation and tisssue damage initially experienced with hormonal contraceptive use.

The correlation between age of subjects and duration of use of hormonal contraceptives showed that the implant contraceptves had a positive correlation with SOD $(r=0.344)$ and GPx $(r=$ 0.3258 ) whereas CAT showed negative correlation $(\mathrm{r}=-0.3880)$ respectively. However, while Fajer et al. also reported negative correlation between the activity of CAT and duration of use of noristerat injection in women in Al-Diwaniya city, Iraq, the correlations between SOD and GSH were found to be negative in that study ${ }^{[39]}$.

\section{Conclusion}

The use of hormonal contraceptives resulted in significant increase in the level of mondialdehyde and catalase activity the contraceptive users. The TAA was reportedly elevated and the correlation between age and the duration of use of the hormonal contraceptives in the implant implant contraceptive users showed positive correlation with SOD and GPx whereas CAT showed a negative correlation. These results, though conflicting, brings to the fore the observation that prolonged use of hormonal contraceptives may reverse the lipid peroxidation and tisssue damage initially experienced with hormonal contraceptive use.

\section{Acknowlegement}

The authors want to acknowledge and appreciate the Ministry of Health, Kaduna State, Nigeria for granting the Ethical Clearance that made it possible for the research to carried out in Family Planning facilities in the State.

\section{Disclosure}

There is no conflict of interest in this atudy.

\section{References}

1 Monjok, E.; Andrea, S.;Ekabua, J. E.; Essien, E. J.Contraceptive practices in Nigeria: Literature review and recommendation for future policy decisions, Open Access Journal of Contraception, 2010,1, 19-22. DOI: 10.2147/OAJC.S9281

2 Otoide,V.O.;Oronsaye, F.; Okonofua, F.E.Why Nigerian adolescents seek abortion rather than contraception: Evidence from focus-group discussions, International Family Planning Perspective, 2001, 27(2), 77-81.

3 Abiodun, O.M.; Balogun, O.R.. Sexual activity and contraceptive use among young female students of tertiary educational institution in Ilorin, Nigeria, Contraception, 2009, 79, 146149.Epub 2008 Nov $17 . \quad$ DOI: 10.1016/J.Contraception.2008.08.002

4 Pincus G, Chang MC, Hafez ES, Zarrow MX, Merrill A. Effects of certain 19-nor steroids on reproductive processes in animals. Science 1956; 124(3227): 890-891 [PMID: 13380400 DOI: $10.1126 /$ science.124.3227.890-a]

5 Erhabor, O.;Isaac, I.Z.; Kaoje, A.U.;John, R.T.; Suleiman, S. A. Assessment of some coagulation parameters among clients on hormonal contraceptive in a tertiary health facility in Sokoto, North Western Nigeria, Journal of Haematology and Thrombotic Disease, 2014, 2, 139. DOI: 10.4172/2329$\underline{8790.1000139}$

6 Mosher, W.D.; Jones, J. Use of contraception in the United States, Vital and Health Statistics, 2010, 23, 1982-2008.

7 Nigeria.Demographic Health Survey;Key Findings, 2013,67-69, 72-74.

8 Palan PR, Magneson AT, Castillo M, Dunne J, Mikhail MS. Effects of menstrual cycle and oral contraceptive use on serum levels of lipidsoluble antioxidants. Am J Obstet Gynecol 
2006; 194(5): e35-38 [PMID: 16647895 DOI: 10.1016/j.ajog.2005.11.032]

9 Akinloye O, Adebayo TO, Oguntibeju OO, Oparinde DP, Ogunyemi EO. Effects of contraceptives on serum trace elements, calcium and phosphorus levels. West Indian Med J 2011; 60(3): 308-315 [PMID: 22224344]

10 Adejumo, E.N.;Adediji, I.O; Akinmulero, A.O. Effect of hormonal contraceptives on the total antioxidant status of women from Isolo, Lagos State, Nigeria, Journal of Biosciences and Medicines, 2016, 4, 107-111. DOI: 10.4236/jbm.2016.41013

11 Pincemail J, Vanbelle S, Gaspard U, Collette G, Haleng J, Cheramy-Bien JP, Charlier C, Chapelle JP, Giet D, Albert A, Limet R, Defraigne JO. Effect of different contraceptive methods on the oxidative stress status in women aged 4048 years from the ELAN study in the province of Liege, Belgium. Hum Reprod 2007; 22(8): 2335-2343 [PMID: 17584753 DOI: $10.1093 /$ humrep/dem146]

12 Halliwell B. Biochemistry of oxidative stress. Biochem Soc Trans 2007; 35(Pt 5): 1147-1150 DOI: $10.1042 / \mathrm{BST} 0351147$

13 Osman, N. N.; Jambi, E. J.; Bashaikh, S. M. Effect of oral contraceptive pills on oxidative stress in diabetic rats, International Journal of Pharmaceutical Research \& Allied Sciences, 2017, 6(2), 171-185. ISSN: 2277-3657

14 Greydanus DE, Patel DR, Rimsza ME. Contraception in the adolescent: an update. Pediatrics 2001; 107(3): 562-573 [PMID: 11230601 DOI: $10.1542 /$ peds.107.3.562]

15 Darney P, Patel A, Rosen K, Shapiro LS, Kaunitz AM. Safety and efficacy of a singlerod etonogestrel implant (Implanon): results from 11 international clinical trials. Fertil Steril 2009; 91(5): 1646-1653 DOI: $\underline{10.1016 / \text { j.fertnstert.2008.02.140 }}$

16 Graesslin O, Korver T. The contraceptive efficacy of Implanon: a review of clinical trials and marketing experience. Eur $\boldsymbol{J}$ Contracept Reprod Health Care 2008; 13 Suppl 1: 4-12 DOI: $10.1080 / 13625180801942754$

17 Naing, L.; Winn, T.;Rusli, B.N. Practical issues in calculating the sample size for prevalence studies, Archives of Orofacial Science, 2006, 1, 9-14. DOI: $\underline{10.1 .504 .2129}$
18 Blackstone, S.R.; Iwelunmor, J. Nigerian couples: evidence from the 2013 Demographic and Health Survey, Contraception and Reproductive Medicine, 2017, 2, 9-11.

19 Lewis, S. M.; Bain, B. J.; Bates, I.Dacie and Lewis Practical Haematology, 10th edn. Lewis, S. M. \& Tatsunmi, N. Ed.; Churchill Livingstone Elsevier, Philadelphia, 2006, pp 1-10

20 Fridovich I. Superoxide radical: an endogenous toxicant. Annu Rev Pharmacol Toxicol 1983; 23: 239-257 [PMID: 6307121 DOI: 10.1146/annurev.pa.23.040183.001323]

21 Okhawa, H.; Ohisi, N.; Yagi, K. Assay of lipid peroxide in animal tissues by thiobarbituric acid reaction, Annals of Biochemistry, 1979, 95, 351-358. DOI:10.1016/00032697(79)90738-3

22 Atawodi, S.E.; Adekunle, O.O.; Bala, I. Antioxidant, organ protective and ameliorative properties of methanol extract of anogeissus leiocarpus stem bark against carbon tetrachloride-induced liver injury,

International Journal of Pharmaceutical Sciences and Research, 2(6), 2011, 1443-1448. DOI:http://dx.doi.org/10.13040/IJPSR.O9758232.2(6).1443-48

23 Aebi, H.Methods of enzymatic analysis, Bergmeyer, H.U., Ed.; New York, 1974, pp 673-677.

24 Rotruck JT, Pope AL, Ganther HE, Swanson AB, Hafeman DG, Hoekstra WG. Selenium: biochemical role as a component of glutathione peroxidase. Science 1973; 179(4073): 588-590 DOI: $10.1126 /$ science.179.4073.588

25 Buico A, Cassino C, Ravera M, Betta PG, Osella D. Oxidative stress and total antioxidant capacity in human plasma. Redox Rep 2009; 14(3): 125-131 [PMID: 19490754 DOI: 10.1179/135100009X392557]

26 Zal F, Mostafavi-Pour Z, Amini F, Heidari A. Effect of vitamin $\mathrm{E}$ and $\mathrm{C}$ supplements on lipid peroxidation and GSH-dependent antioxidant enzyme status in the blood of women consuming oral contraceptives. Contraception 2012; 86(1): 62-66 [PMID: 22494786 DOI: 10.1016/j.contraception.2011.11.006]

27 Davies, M.J.Direct detection of peroxyl radicals formed in the reactions of metmyoglobin and 
methaemoglobin with t-butyl hydroperoxide, Free Radicals Research Communications, 1989, 7: 27-32. DOI: 10. $10.3109 / 10715768909088158$

28 Gaetani GF, Ferraris AM, Rolfo M, Mangerini $\mathrm{R}$, Arena S, Kirkman HN. Predominant role of catalase in the disposal of hydrogen peroxide within human erythrocytes. Blood 1996; 87(4): 1595-1599 [PMID: 8608252]

29 Chelikani P, Fita I, Loewen PC. Diversity of structures and properties among catalases. Cell Mol Life Sci 2004; 61(2): 192-208 [PMID: 14745498 DOI: $10.1007 / \mathrm{s} 00018-003-3206-5]$

30 Adaramoye, O.A.; Farombi, E. O.; Emerole, G.O. Comparative study of the antioxidant properties of flavonoids of Garcinia kola seeds, Paskistan Journal of Medical Science, 2005, 21, 331-339

31 Adedara IA, Awogbindin IO, Anamelechi JP, Farombi EO. Garcinia kola seed ameliorates renal, hepatic, and testicular oxidative damage in streptozotocin-induced diabetic rats. Pharm Biol 2015; 53(5): 695-704 [PMID: 25243878 DOI: $10.3109 / 13880209.2014 .937504]$

32 Capel ID, Jenner M, Williams DC, Donaldson D, Nath A. The effect of prolonged oral contraceptive steroid use on erythrocyte glutathione peroxidase activity. $\boldsymbol{J}$ Steroid Biochem 1981; 14(8): 729-732 [PMID: 6795391 DOI: $10.1016 / 0022-4731(81) 90008-$ x]
33 Massafra C, Buonocore G, Berni S, Gioia D, Giuliani A, Vezzosi P. Antioxidant erythrocyte enzyme activities during oral contraception. Contraception 1993; 47(6): 590-596 DOI: 10.1016/0010-7824(93)90026-4]

34 Smith JL, Goldsmith GA, Lawrence JD. Effects of oral contraceptive steroids on vitamin and lipid levels in serum. Am $\boldsymbol{J}$ Clin Nutr 1975; 28(4): 371-376 [PMID: 1119433 DOI: 10.1093/ajen/28.4.371]

35 Speroff, L.; Darney, P. D. A Clinical Guide for Contraception. 2nd Ed. William and Wilkins, Baltimore, USA., 1996, pp.247.

36 Brennan P, Bankhead C, Silman A, Symmons D. Oral contraceptives and rheumatoid arthritis: results from a primary care-based incident case-control study. Semin Arthritis Rheum 1997; 26(6): 817-823 [PMID: 9213380 DOI: 10.1016/s0049-0172(97)80025-x]

37 Benet LZ. Effect of route of administration and distribution on drug action. J Pharmacokinet Biopharm 1978; 6(6): 559-585 [PMID: 731418 DOI: $10.1007 / \mathrm{bf01062110]}$

38 Mangoni AA, Jackson SH. Age-related changes in pharmacokinetics and pharmacodynamics: basic principles and practical applications. Br $\boldsymbol{J}$ Clin Pharmacol 2004; 57(1): 6-14 DOI: 10.1046/j.13652125.2003.02007.x

39 Fajer, A. N.; Aboud, H K.; Norezaq, N. E. A. The side effect of noristerat injection in some biochemistry parameters in Al-Diwaniya city, Pakistani Journal of Biotechnology, 2018, 15 (3) 699-702 (2018). ISSN Online: 2312-7791 